\title{
Computer Anxiety, Computer Self-Efficacy dan Perceived Usefulness oleh Pelaku UMKM
}

\author{
Rena Widiyasari \\ Bety Nur Achadiyah \\ Universitas Negeri Malang \\ Jalan Semarang 5, Malang, Indonesia, 65145 \\ renawidiyasari8@gmail.com
}

\begin{abstract}
This study aims to examine the interest of MSME owners in using accounting information technology with the influence of computer anxiety, computer self-efficacy, and perceived usefulness. This study used a quantitative research design and data collection techniques using the questionnaire method. The results showed that computer anxiety had a negative effect on the interest of MSMEs in applying accounting information technology, because of the high fear and low sense of anticipation would further reduce interest. Meanwhile, computer self-efficacy and perceived usefulness variables have a positive effect on the interest of MSME owners in applying accounting information technology. With these results, it is expected to increase the awareness of MSME owners to apply accounting information technology in their business.
\end{abstract}

Keywords: Computer Anxiety, Computer Self-Efficacy, Perceived Usefulness, IT, MSMEs.

\begin{abstract}
Abstrak
Penelitian ini menguji minat pelaku UMKM terhadap penggunaan teknologi informasi akuntansi dengan adanya pengaruh dari computer anxiety, computer self-efficacy, dan perceived usefulness. Penelitian ini menggunakan rancangan penelitian kuantitatif dan teknik pengumpulan data menggunakan metode kuisioner. Hasil penelitian menunjukkan bahwa computer anxiety berpengaruh negatif terhadap minat pelaku UMKM dalam menerapkan teknologi informasi akuntansi, karena tingginya rasa takut dan rendahnya rasa antisipasi akan semakin mengurangi minat. Sedangkan, variabel computer self-efficacy dan perceived usefulness berpengaruh positif terhadap minat pelaku UMKM dalam menerapkan teknologi informasi akuntansi. Dengan adanya hasil ini, diharapkan dapat meningkatkan kesadaran para pelaku UMKM untuk menerapkan teknologi informasi akuntansi dalam usahanya.
\end{abstract}

Kata Kunci: Kecemasan Komputer, Efikasi Diri Komputer, Kegunaan yang Dipersepsikan, IT, UMKM

\section{PENDAHULUAN}

Usaha Mikro Kecil Menengah (UMKM) merupakan salah satu pilar utama dalam menggerakkan ekonomi negara Indonesia (Rosianti \& Mahendrawati, 2017). Namun sayangnya, perkembangan UMKM masih terkendala oleh berbagai masalah terutama akibat pencatatan yang buruk atau tidak tersedianya catatan keuangan sehingga menyebabkan salah kelola sumber daya (Dawuda \& Azeko, 2015). Meskipun banyak faktor lain yang mempengaruhi UMKM tetapi persoalan-persoalan di UMKM lazimnya muncul akibat kegagalan mengelola dana (Kurniawati, dkk., 2012). Kegagalan tersebut diakibatkan oleh manajemen keuangan UMKM yang belum tertata rapi, antara biaya dan pemasukan (Lestiawan \& Mahmud, 2014). Akibat dari tidak tersedianya pencatatan keuangan yang tepat, keputusan manajerial yang diambil pun sering kali tidak tepat dan justru merugikan (Kurniawan \& Diptyana, 2011). Padahal, melalui pelaporan keuangan yang tepat, efektif dan efisien, peningkatan pertumbuhan ekonomi melalui kontribusi UMKM akan dapat dicapai (Ezeagba, 2017). Hal ini menunjukkan bahwa perlu didakannya pencatatan keuangan yang akurat dan dapat diandalkan sehingga tidak terjadi salah pengelolaan usaha.

Di era digital ini, para pelaku UMKM dapat memperbaiki pencatatan keuangannya dengan menerapkan akuntansi berbasis teknologi informasi. Dengan hadirnya teknologi informasi, pencatatan akuntansi dapat dilakukan secara otomatis, sehingga lebih akurat (Saban \& Efeoglu, 2012). Otomatisasi yang ada dalam teknologi informasi juga menyederhanakan pencatatan akuntansi menjadi lebih cepat dan efisien (Hesam, 2017). Hal ini tentu akan sangat membantu para pelaku UMKM yang tidak semuanya memiliki latar belakang akuntansi, sehingga dapat melakukan 
pencatatan dengan tepat dan tidak perlu mempelajari tahapan demi tahapan siklus akuntansi manual. Dengan adanya pencatatan yang baik keputusan manajerial yang diambil dapat menjadi lebih berkualitas (Kurniawan \& Diptyana, 2011). Berbagai kelebihan tersebut membuat perusahaan yang menerapkan akuntansi berbasis teknologi informasi akan lebih unggul melawan perusahaan dengan sistem tradisional (Hesam, 2017).

Meski dibutuhkan, UMKM nyatanya masih jauh lebih lambat dari perusahaan berskala besar dalam hal penerapan teknologi informasi untuk akuntansi. Di Kota Malang, diketahui bentuk praktik akuntansi pada UMKM masih sangatlah sederhana, dan bahkan tidak ada (Andarsari \& Dura, 2018). Hal tersebut diperparah dengan diumumkan bahwa hanya 3\% saja UMKM di Kota Malang yang sudah go online (Kemkominfo, 2017). Padahal, dengan adanya go online UMKM akan semakin mudah untuk mengakses pelayanan internet termasuk teknologi informasi akuntansi yang berbasis online (cloud accounting). Cloud accounting dapat menjadi salah satu alternatif untuk UMKM agar dapat bersaing dengan perusahaan besar di era global dengan pencatatan akuntansi yang tepat dan lengkap (Rumetna \& Sembiring, 2017). Salah satu bentuk cloud accounting tersebut ialah BeeUKM, Lamikro, dan GoUKM yang telah disesuaikan dengan kebutuhan UMKM.

Rendahnya minat UMKM untuk menerapkan teknologi informasi terlebih di bidang akuntansi diketahui karena adanya ketidaksiapan dari pelaku UMKM itu sendiri (Rosianti \& Mahendrawati, 2017). Teknologi informasi akuntansi yang terdiri dari kegiatan komputerisasi tersebut dianggap sebagai suatu hal baru dan belum dikuasai sehingga memunculkan kecemasan pada diri penggunanya (Harrison \& Rainer, 1992). Hal inilah yang disebut computer anxiety dan akan mengakibatkan kesulitan dan ketakutan bahkan sebelum menjalankan komputer itu sendiri (Saade \& Kira, 2009). Akibatnya, computer anxiety akan mengurangi intensitas penggunaan komputer (Achim \& Kassim, 2015). Dengan timbulnya kecemasan berkomputer (computer anxiety) di kalangan pengguna termasuk pelaku UMKM, hal tersebut akan mengurangi minat mereka untuk menggunakan software akuntansi.

Kegelisahan dalam berkomputer dapat diatasi dengan meningkatkan kemampuan dalam mengoperasikan komputer (Saade \& Kira, 2009). Dengan adanya peningkatan kemampuan, seseorang akan memiliki kepercayaan diri dalam mengoperasikan komputer atau yang biasa disebut computer self-efficacy (CSE). Konsep self-efficacy berasal dari teori sosial kognitif oleh Bandura (1986), yang kemudian dikembangkan pada penerimaan teknologi menjadi CSE oleh Compeau dan Higgins, pada tahun 1995. CSE merupakan penilaian kapabilitas dan keahlian komputer seseorang untuk melakukan tugas-tugas yang berhubungan dengan teknologi informasi (Compeau \& Higgins, 1995). Dengan adanya CSE, penggunaan komputer menjadi sesuatu yang dianggap dapat dikuasai sehingga tidak perlu dihindari (Putra \& Nugroho, 2016).

Terlepas dari sulit atau mudahnya penggunaan, penerapan teknologi informasi akuntansi pada UMKM tetap tidak bisa diabaikan begitu saja karena bagaimanapun juga penggunannya akan memberikan manfaat bagi penggunanya. Individu akan memilih menggunakan suatu teknologi informasi jika mengetahui manfaat positif dari penggunaannya (Thompson, et. al., 1991). Manfaat dari penggunaan teknologi informasi akuntansi sangat perlu untuk ditekankan kepada pelaku UMKM sehingga dapat menumbuhkan persepsi kegunaan (perceived usefulness).

Pada penelitian-penelitian sebelumnya (Saade \& Kira, 2009; Putra \& Nugroho, 2016; Hamid, et. al., 2016), faktor-faktor yang mempengaruhi minat penggunaan teknologi informasi akuntansi seperti computer anxiety, computer self-efficacy dan perceived usefulness belum pernah diujikan pada pelaku UMKM yang sebenarnya merupakan pihak yang sangat membutuhkan informasi akuntansi. Untuk itu dalam studi ini, masalah yang akan dikaji yaitu apakah terdapat pengaruh antara computer anxiety, computer self-efficacy dan perceived usefulnes terhadap minat pelaku UMKM dalam menerapkan teknologi informasi akuntansi.

\section{Landasan Teori}

Studi ini didukung oleh pendekatan Technology Acceptance Model (TAM). TAM adalah suatu model pendekatan keperilakuan yang dikembangkan oleh Davis (1986) yang diadaptasi dari Theory of Reasoned Action (TRA) yang dicetuskan oleh Ajzen 1980. Berbeda dengan TRA, Davis (1986) lebih mengkhususkan TAM untuk menjelaskan terbentuknya perilaku dalam penggunaan 
teknologi. TAM dinilai lebih spesifik dalam menjelaskan hubungan dari komponen perilaku penggunaan teknologi komputer sebagaimana tercermin dalam Gambar 1.

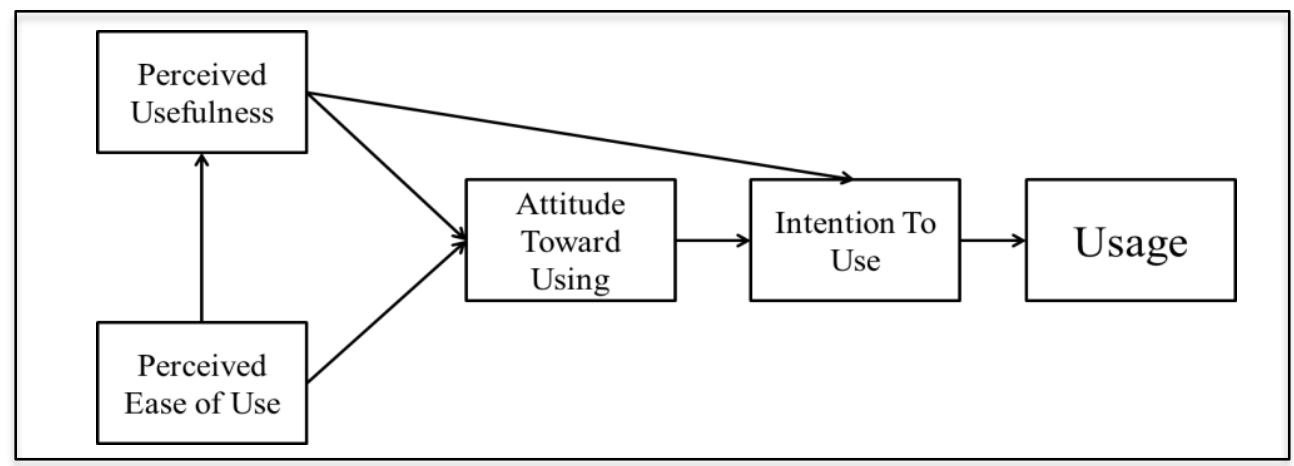

Gambar 1. Technology Acceptance Model (Sumber: Davis, 1986:43)

Pada studi ini, konsep kepercayaan yang digunakan hanyalah perceived usefulness. Dalam TAM, Davis, et. al. (1989) telah menjelaskan, meskipun terdapat dua konstruk kepercayaan, namun perceived usefulness memiliki pengaruh yang lebih signifikan dalam penggunaan teknologi. Besarnya pengaruh dari perceived usefulness terhadap penerimaan teknologi juga telah dibuktikan, bahkan tanpa melalui pengujian persepsi kemudahan (Igbaria, et. al., 1994; Lindblom et. al., 2012; Welliam, 2012). Hal ini dikarenakan individu akan cenderung memilih untuk meggunakan teknologi jika mengetahui manfaat positif dari penggunaannya (Thompson et al., 1991) Munculnya persepsi tersebut diyakini dapat meningkatkan minat penggunaan teknologi infomasi akuntansi termasuk oleh pelaku UMKM.

Alasan tidak digunakannya perceived ease of use adalah karena dalam penggunaan teknologi informasi, sesulit apapun sistem yang ada, tetap akan dapat dikuasai apabila seseorang memiliki keyakinan yang kuat atas kemampuan yang dimilikinya (Compeau \& Higgins, 1995). Akibatnya, minat untuk menggunakan teknologi tidak terlalu terpengaruh persepsi kemudahan, melainkan lebih terpengaruh oleh manfaat penggunaan teknologi (Hamid et. al., 2016). Bahkan, ditemukan bahwa tidak ada keterkaitan pengaruh antara persepsi kemudahan terhadap minat penggunaan teknologi (Rakhmawati \& Isharijadi, 2013). Hal itulah yang menyebabkan pengaruh dari variabel eksternal dapat lebih signifikan dibandingkan persepsi kemudahan (Lee, et. al., 2000).

Davis menjelaskan bahwa selain variabel yang terdapat dalam konstruk utama TAM, masih terdapat variabel eksternal yang dapat mempengaruhi penggunaan teknologi (Davis et. al., 1989). Variabel eksternal tersebut berupa faktor intrinsik yang muncul dari dalam diri pengguna seperti anxiety dan self-efficacy, serta faktor ekstrinsik yaitu faktor lingkungan seperti faktor sosial dan koneksi internet (Venkatesh, et. al., 2002). Untuk itu, selain menguji variabel perceived usefulness, pengujian ini juga dilakukan pada variabel lain yaitu computer anxiety dan computer self-efficacy yang merupakan variabel penting pada studi perilaku individual dalam penggunaan teknologi komputer (Irmadhani \& Mahendra, 2012).

\section{Computer Anxiety dan Minat Menerapkan Teknologi Informasi Akuntansi}

Dalam TAM telah dijelaskan bahwa munculnya minat penggunaan teknologi didasari oleh keyakinan (belief) (Davis, 1986). Computer anxiety juga merupakan suatu bentuk keyakinan diri individu atas kegelisahan dalam penggunaan komputer. Meskipun computer anxiety bukan merupakan konstruk utama dalam TAM, namun computer anxiety dapat menjadi salah satu dari variabel eksternal karena lebih spesifik terhadap penerimaan individu terhadap teknologi (Harrison \& Rainer, 1992). Terlebih lagi, munculnya computer anxiety dapat menimbulkan ketakutan sehingga seseorang akan cenderung menganggap penggunaan komputer akan menjadi lebih sulit. Keberadaan computer anxiety yang mempengaruhi pengguna komputer telah dijelaskan akan mengganggu performanya oleh karena itu, computer anxiety juga berpengaruh negatif pada performance (Jahromi et. al., 2016). Penelitian lain juga menemukan bahwa computer anxiety akan berpengaruh negatif pada minat penggunaan software akuntansi (Putra \& Nugroho, 2016). Penelitian terdahulu juga 
menemukan bahwa computer anxiety berpengaruh negatif terhadap perceived ease of use (Saade \& Kira, 2009). Hal ini berarti semakin tinggi computer anxiety maka penggunaan teknologi akan dirasa semakin sulit. Hasil lain menemukan bahwa computer anxiety berpengaruh negatif terhadap sikap seseorang dalam menggunakan komputer, yang artinya munculnya computer anxiety akan membuat sikap seseorang merasa tidak senang dengan penggunaan komputer (Hsiao, et. al., 2010). Berdasarkan teori dan berbagai penelitian yang mendukung, computer anxiety dianggap dapat membuat pelaku UMKM dapat semakin enggan untuk menerapkan teknologi informasi akuntansi, sehingga hipotesis dalam studi ini sebagai berikut.

$\mathrm{H}_{1}$ : Computer anxiety berpengaruh negatif terhadap minat pelaku UMKM menerapkan teknologi informasi akuntansi.

\section{Computer Self-Efficacy (CSE) dan Minat Menerapkan Teknologi Informasi Akuntansi}

CSE memiliki dimensi yang sama dengan self-efficacy dari Bandura (1986) karena samasama merupakan keyakinan individu atas kemampuannya menjalankan suatu perilaku, namun CSE terbatas pada penggunaan teknologi komputer. Konsep tersebut juga sesuai apabila disandingkan dengan konsep keyakinan dalam TAM karena dapat mempengaruhi penggunaan teknologi. Untuk itu, CSE tentu layak diujikan sebagai variabel eksternal dalam TAM. Terdapat penelitian yang menemukan bahwa CSE berpengaruh positif terhadap penggunaan komputer yang berarti semaakin tinggi CSE maka semakin meningkat pula penggunaan komputernya (Achim \& Kassim, 2015). Penemuan lain juga mendukung pengaruh positif CSE terhadap perceived ease of use (Saade \& Kira, 2009). Hal ini berarti semakin tinggi CSE maka penggunaan teknologi akan dirasa semakin mudah. CSE berpengaruh positif terhadap performa seseorang dalam penggunaan teknologi, sehingga meningkatkan performa seseorang saat menggunakan teknologi (Jahromi et al., 2016). CSE juga berpengaruh positif terhadap minat seseorang untuk menggunakan software akuntansi, yang menunjukkan bahwa minat seseorang akan meningkat dengan adanya CSE (Putra \& Nugroho, 2016). Dalam studi ini, dengan adanya CSE, pelaku UMKM dianggap tidak perlu lagi menghindari penggunaan komputer dan semakin yakin untuk terus menggunakannya. Berdasarkan teori dan berbagai penelitian yang mendukung, hipotesis dalam studi ini sebagai berikut.

$\mathrm{H}_{2}$ : Computer self-efficacy berpengaruh positif terhadap minat pelaku UMKM menerapkan teknologi informasi akuntansi.

\section{Perceived Usefulness dan Minat Menerapkan Teknologi Informasi Akuntansi}

Berdasarkan pendekatan Technology Acceptance Model (TAM) perceived usefulness merupakan komponen didalamnya yang dapat berpengaruh langsung terhadap intention to use atau minat untuk menggunakan suatu teknologi. Perceived usefulness diartikan sebagai tingkat keyakinan individu bahwa dalam menggunakan sistem atau teknologi tertentu akan meningkatkan kualitas kerjanya. Pengaruh perceived usefulness terhadap penggunaan teknologi juga telah dibahas pada berbagai penelitian terdahulu. Terdapat studi yang menemukan bahwa perceived usefulness berpengaruh positif terhadap sikap seseorang dalam menggunakan sistem online, yang artinya manfaat yang akan diterima akan membuat sikap seseorang merasa senang dengan penggunaan sistem online (Renny, et. al., 2013). Selanjutnya, perceived usefulness juga berpengaruh positif terhadap minat menggunakan e-marketing, karena dirasa akan memberikan manfaat dan meningkatkan kinerja pemasaran (Kanchanatanee, et. al., 2014). Penemuan lain juga mendukung pengaruh positif perceived usefulness terhadap penggunaan teknologi informasi (Anggraeni, 2015). Penelitian lain menemukan bahwa perceived usefulness berpengaruh pula terhadap minat berkelanjutan menggunakan sistem e-government (Hamid, et. al., 2016). Hal ini dikarenakan manfaat yang diperoleh dari penggunaan dapat terus diterima hingga penggunaan di masa yang akan datang. Hasil yang sama juga ditunjukkan dalam studi perceived usefulness terhadap minat penggunaan media sosial dalam e-learning yang memiliki hubungan positif (Elkaseh, et. al, 2016). Dalam studi ini, perceived usefulness juga dinilai mampu meningkatkan minat pelaku UMKM untuk menerapkan teknologi informasi akuntansi karena mengetahui manfaat yang akan diperoleh. Berdasarkan teori dan berbagai penelitian yang mendukung,, hipotesis studi ini adalah sebagai berikut. 
$\mathrm{H}_{3}$ : Perceived usefulness berpengaruh positif terhadap minat pelaku UMKM dalam menerapkan teknologi informasi akuntansi.

\section{METODE}

Metode penelitian yang digunakan dalam studi ini adalah metode kuantitatif. Variabel dependen terdiri dari minat untuk menerapkan teknologi informasi akuntansi, dan variabel independen terdiri dari computer anxiety, computer self-efficacy dan perceived usefulness. Jika digambarkan, hubungan variabel pada penelitian ini dapat dilihat pada Gambar 2.

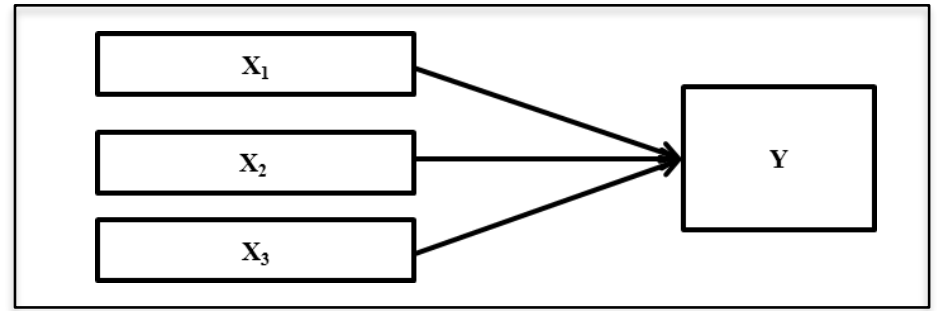

Gambar 2. Desain Penelitian

Keterangan:

$\mathrm{X}_{1} \quad=$ Computer Anxiety

$\mathrm{X}_{2} \quad=$ Computer Self-Efficacy

$\mathrm{X}_{3} \quad=$ Perceived Usefulness

Y = Minat Menerapkan Teknologi Informasi Akuntansi

$\longrightarrow=$ Pengaruh Variabel Independen Terhadap Variabel Dependen

\section{Variabel Penelitian}

Pada studi ini terdapat total empat variabel. Variabel pertama yang merupakan variabel dependen adalah minat menerapkan teknologi informasi akuntansi. Minat adalah keinginan atau niat yang muncul dalam diri seseorang atas kesadarannya untuk melakukan suatu tindakan tertentu atau mencoba suatu hal baru. Indikator yang dipakai untuk mengukur minat terdiri dari keinginan menggunakan, selalu mencoba menggunakan dan berlanjut menggunakan di masa depan (Hanggono, dkk., 2015). Dari indikator-indikator tersebut, dibuatlah tujuh pernyataan yang dapat menggambarkan minat penerapan teknologi informasi akuntansi. Variabel ini diukur dengan menggunakan Skala Likert dari Sangat Tidak Setuju (STS) dengan skor satu sampai Sangat Setuju (SS) dengan skor enam. Skor dari variabel minat diperoleh dengan menjumlahkan respon dari setiap pernyataan (Siregar, 2013:27).

Variabel selanjutnya yang merupakan variabel independen adalah computer anxiety. Computer anxiety merupakan perasaan khawatir dan cemas dari seorang individu yang akan muncul jika ia dihadapkan pada penggunaan teknologi komputer. Indikator yang digunakan dalam variabel computer anxiety adalah fear (takut) dan anticipation (antisipasi). (Harrison \& Rainer, 1992). Indikator tersebut kemudian dijabarkan menjadi delapan pernyataan yang juga diukur dengan menggunakan Skala Likert dari Sangat Tidak Setuju (STS) dengan skor satu sampai Sangat Setuju (SS) dengan skor enam. Respon dari setiap pertanyaan kemudian dijumlahkan untuk memperoleh skor variabel computer anxiety (Siregar, 2013:27).

Selanjutnya variabel computer self-efficacy (CSE) yang merupakan suatu keyakinan diri yang dimiliki seseorang atas kemampuannya dalam menguasai hal-hal yang berhubungan dengan komputer. Sesorang dengan CSE tinggi akan menilai dirinya mampu menyelesaikan pekerjaan yang berhubungan dengan penggunaan komputer. Indikator yang digunakan adalah magnitude, strength, dan generalizability (Compeau \& Higgins, 1995). Magnitude mengacu pada level kapabilitas seseorang dalam penggunaan komputer dengan baik. Strength mengacu pada level keyakinan dirinya tentang kemampuan individu itu sendiri apakah mampu menyelesaikan komputerisasi akuntansi. Generalizability mengacu pada kemampuan menggunakan paket-paket software dan sistem yang berbeda-beda dibandingkan dengan individu dengan level generalizability yang lebih rendah. Ketiga indikator tersebut kemudian dijabarkan menjadi sembilan pernyataan. Skala Likert juga digunakan 
untuk mengukur variabel CSE dari Sangat Tidak Setuju (STS) dengan skor satu sampai Sangat Setuju (SS) dengan skor enam. Respon tersebut kemudian dijumlahkan menjadi skor total (Siregar, 2013:27).

Variabel terakhir ialah perceived usefulness yang merupakan suatu anggapan yang dimiliki individu terhadap manfaat yang akan mereka terima apabila menggunakan suatu teknologi. Perceived usefulness merupakan persepsi pribadi yang memandang manfaat penggunaan suatu teknologi terlepas dari mudah atau tidaknya penggunaan. Indikator perceived usefulness meliputi improves job performance, increases productivity, enhances effectiveness, dan the system is useful (Venkatesh \& Davis, 2000). Improves job performance adalah peningkatan kinerja, increases productivity adalah peningkatan produktivitas yaitu output laporan keuangan yang secara tidak langsung meningkatkan produktivitas, enhances effectiveness berkaitan dengan penghematan waktu dalam menyelesaikan tugas, the system is useful adalah berkaitan dengan seberapa bermanfaatkah suatu teknologi. Indikator-indikator tersebut dikembangkan menjadi delapan pernyataan yang selanjutnya juga diukur dengan menggunakan Skala Likert dari Sangat Tidak Setuju (STS) dengan skor satu sampai Sangat Setuju (SS) dengan skor enam. Angka-angka dari respon setiap pernyataan kemudian dijumlahkan (Siregar, 2013:27).

\section{Sampel}

Ukuran sampel yang layak diteliti adalah antara 30 hingga 500 sampel (Sugiyono, 2014:116). Sampel minimal untuk penelitian dengan multivariate adalah 10 kali dari jumlah variabel yang diuji (Rescue dalam Sugiyono, 2014:116). Dalam studi ini, variabel yang akan diuji berjumlah empat termasuk variabel dependen. Oleh karena itu, jumlah sampel yang akan digunakan ialah 40 UMKM. Terdapat banyak jumlah unit dan sektor usaha dari UMKM yang sulit untuk diidentifikasi. Untuk itu, pengambilan sampel menggunakan teknik cluster sampling dengan memilih empat kelompok UMKM berdasarkan sektor yang paling banyak dijumpai di Kota Malang yaitu industri kuliner, industri kerajinan dan fashion, perdagangan serta jasa. Selanjutnya, pada setiap cluster ditetapkan 10 UMKM sebagai sampelnya agar dapat memenuhi jumlah sampel yang dibutuhkan.

\section{Instrumen Penelitian}

Jenis data yang digunakan dalam penelitian ini adalah data pimer dan teknik pengumpulan datanya menggunakan kuesioner. Kuesioner tersebut dibagi menjadi lima bagian. Bagian pertama dari kuesioner merupakan bagian identitas diri responden, dimana responden diminta untuk mengisi identitas dari UMKM. Untuk menjaga kerahasiaan atau confidentiality dari responden, hasil pengisian pada bagian ini tidak akan diungkap maupun dilampirkan, melainkan hanya diketahui oleh peneliti sebagai petunjuk pemisahan cluster. Bagian kedua hingga kelima kuesioner terdiri dari pernyataan atas setiap variabel. Total pernyataan dari bagian-bagian tersebut adalah 32 pernyataan. Semuanya diukur dengan skala likert 1-6 untuk respon sangat tidak setuju hingga sangat setuju.

\section{Metode Analisis Data}

Ada beberapa tahapan dalam analisis data penelitian ini. Tahapan pertama dilakukan pengujian instrumen dengan diadakannya pilot test. Pilot test dilakukan pada 30 responden diluar sampel penelitian. Hasil dari pilot test kemudian diuji validitas dan reliabilitasnya. Tahapan kedua dilakukan uji asumsi klasik yaitu uji normalitas, uji multikolinearitas, dan uji heteroskedastisitas. Uji autokorelasi tidak dilakukan karena tidak menggunakan data time series. Tahapan ketiga adalah dianalisis dengan regresi linear berganda untuk menguji hipotesis dengan persamaan sebagai berikut.

$\mathrm{Y}=\mathrm{a}+\mathrm{b}_{1} \mathrm{X}_{1}+\mathrm{b}_{2} \mathrm{X}_{2}+\mathrm{b}_{3} \mathrm{X}_{3}+\mathrm{ei}$

Keterangan:

$\mathrm{Y}=$ Minat Menerapkan Teknologi Informasi Akuntansi

$\mathrm{X}_{1}=$ Computer Anxiety

$\mathrm{X}_{2} \quad=$ Computer Self-Efficacy

$\mathrm{X}_{3}=$ Perceived Usefulness 
$\mathrm{a} \quad=$ Konstanta

$\mathrm{b}_{1} \quad=$ Koefisien regresi variabel independen 1

$\mathrm{b}_{2} \quad=$ Koefisien regresi variabel independen 2

$\mathrm{b}_{3} \quad=$ Koefisien regresi variabel independen 3

ei $\quad=$ Variabel lain yang tidak diteliti

\section{HASIL DAN PEMBAHASAN}

Data yang diperoleh dari pilot test digunakan untuk uji validitas dan reliabilitas. Uji validitas dilakukan dengan tabel korelasi product moment dengan hasil yang menunjukkan terdapat dua pernyataan pada variabel CSE yang tidak valid, yaitu poin kedua dan keenam sehingga kedua poin tersebut kemudian dihilangkan. Untuk uji validitas, diketahui bahwa dengan nilai taraf signifikan $5 \%$, nilai koefisien croncbach's alpha dari keempat variabel lebih tinggi dari 0,60. Hal ini menunjukkan bahwa instrumen dari keempat variabel penelitian telah reliabel (Nunnally, 1967:226). Setelah instrumen diketahui valid dan reliabel, dilakukan penelitian untuk menguji hipotesis pada 40 responden.

Sebelum hasil penelitian dianalisis dengan regresi linear berganda, model regresi harus memenuhi ketiga asumsi klasik yaitu normalitas, multikolinearitas dan heteroskedastisitas. Berdasarkan hasil uji normalitas menggunakaan test of kolmogrov-smirnov, data yang diperoleh telah terditribusi normal karena nilai signifikansi kolmogrov-smirnov > 0,05, yaitu 0,684 (Ghozali, 2009:176). Pada uji multikolinearitas, diketahui bahwa semua variabel independen memiliki nilai tolerance $>0,1(10 \%)$ dan nilai VIF < 10 (Ghozali, 2009:140). Artinya, tidak terjadi multikolinearitas antar variabel dalam model regresi. Selanjutnya uji heteroskedastisitas dilakukan dengan uji glejser. Berdasarkan hasil uji glejser diketahui bahwa nilai siginifikansi dari ketiga variabel yang sama-sama di atas 0,05, sehingga dapat disimpulkan bahwa studi ini bebas dari heteroskedastisitas (Ghozali, 2009:139). Dari semua hasil pengujian tersebut, dapat disimpulkan bahwa model regresi telah memenuhi asumsi klasik.

Selanjutnya dilakukan analisis linear berganda untuk menguji hipotesis dengan hasil sebagaimana terlihat dalam Tabel 1.

Tabel 1. Hasil Analisis Linear Berganda

\begin{tabular}{|c|c|c|c|c|c|}
\hline \multirow[b]{2}{*}{ Model } & \multicolumn{2}{|c|}{$\begin{array}{l}\text { Unstandardized } \\
\text { Coefficients }\end{array}$} & \multirow{2}{*}{$\begin{array}{c}\text { Standardized } \\
\text { Coefficients } \\
\text { Beta }\end{array}$} & \multirow[b]{2}{*}{$\mathrm{T}$} & \multirow[b]{2}{*}{ Sig. } \\
\hline & $\mathrm{B}$ & Std. Error & & & \\
\hline (Constant) & 11,385 & 6,991 & & 1,682 & 0,112 \\
\hline Computer Anxiety & $-0,318$ & 0,132 & $-0,277$ & $-2,408$ & 0,021 \\
\hline Computer Self-Efficacy & 0,312 & 0,146 & 0,248 & 2,138 & 0,039 \\
\hline Perceived Usefulness & 0,502 & 0,122 & 0,470 & 4,110 & 0,000 \\
\hline
\end{tabular}

Sumber: hasil olahan

Berdasarkan hasil analisis dari Tabel 1 diketahui bahwa nilai konstanta sebesar 11,385 menyatakan bahwa jika tidak terdapat computer anxiety, computer self-efficacy dan perceived usefulness yang dimiliki oleh individu, maka minat menerapkan Teknologi Informasi Akuntansi bernilai positif yaitu sebesar 11,385. Angka tersebut merupakan total skor minat yang berada pada interval sangat rendah. Kesimpulannya, tanpa adanya computer anxiety, computer self-efficacy dan perceived usefulness, minat untuk menerapkan teknologi informasi akuntansi sangatlah rendah. Nilai koefisien regresi variabel computer anxiety (X1) bernilai negatif yaitu sebesar -0,318 menyatakan bahwa setiap peningkatan skor computer anxiety sebesar 1 skor akan menurunkan minat untuk menerapkan teknologi informasi akuntansi pada diri individu sebesar 0,318 dengan asumsi variabel lain bernilai tetap. Nilai koefisien regresi variabel computer self-efficacy (X2) bernilai positif yaitu sebesar 0,312 menyatakan bahwa setiap peningkatan sifat computer self-efficacy sebesar 1 skor akan meningkatkan minat untuk menerapkan teknologi informasi akuntansi pada diri individu sebesar 0,312 skor dengan asumsi variabel lain bernilai tetap. Nilai koefisien regresi variabel perceived usefulness (X3) bernilai positif yaitu sebesar 0,502 menyatakan bahwa setiap peningkatan perceived 
usefulness sebesar 1 skor pengetahuan akan meningkatkan minat untuk menerapkan teknologi informasi akuntansi pada diri individu sebesar 0,502 skor dengan asumsi variabel lain bernilai tetap.

Berdasarkan uji $\mathrm{F}$ dapat diambil kesimpulan bahwa terdapat pengaruh variabel computer anxiety, computer self-efficacy dan perceived usefulness terhadap variabel dependen minat menggunakan teknologi informasi akuntansi secara simultan atau bersama-sama. Dengan adanya pengaruh secara simultan, selanjutnya dapat dilakukan uji parsial sebagaimana terlihat pada Tabel 2.

Tabel 2. Uji Simultan

\begin{tabular}{cccc}
\hline Signifikansi t & $\alpha=0,05$ & Kondisi & Kesimpulan \\
\hline 0,00 & 0,05 & Sig. $\mathrm{F} \leq 0,05$ & Terdapat pengaruh secara simultan \\
\hline
\end{tabular}

Sumber: hasil olahan

Berdasarkan Tabel 2, hasil dari uji parsial menunjukkan bahwa semua hipotesis diterima. Hal ini diketahui dari setiap variabel yaitu computer anxiety, computer self-efficacy dan perceived usefulness yang memiliki signifikansi lebih dari 0,05 terhadap minat.

\section{PEMBAHASAN}

Hasil pengujian hipotesis yang pertama pada Tabel 2, data menunjukkan bahwa computer anxiey berpengaruh negatif terhadap minat untuk menerapkan teknologi informasi akuntansi. Artinya semakin tinggi kecemasan pelaku UMKM terhadap komputer, maka minat untuk menerapkan teknologi informasi akuntansi pada usahanya semakin rendah, dan sebaliknya pelaku UMKM dengan computer anxiety rendah justru memiliki keinginan untuk menerapkan teknologi informasi akuntansi. Hasil studi ini menunjukkan bahwa dalam TAM yang dikembangkan oleh Davis (1986), masih terdapat faktor lain yang tidak terdapat pada konstruk utama TAM padahal dapat mempengaruhi penerimaan teknologi yaitu faktor intrinsik yang berasal dari dalam diri individu dan faktor ekstrinsik yang berasal dari luar individu (Venkatesh et. al., 2002). Kaitannya dengan faktor eksternal tersebut, computer anxiety yang merupakan kegelisahan atas penggunaan teknologi komputer dapat dikategorikan sebagai faktor intrinsik yang muncul dari dalam individu itu sendiri. Tingginya kegelisahan cenderung akan mengintimidasi seseorang dan mengakibatkan penggunaan teknologi akan terasa semakin sulit. Dalam TAM, keyakinan atas sulitnya penggunaan teknologi akan membuat seseorang cenderung menghindari penggunaan teknologi informasi akuntansi sehingga akan menurunkan minat penggunaan teknologi tersebut, begitupula sebaliknya. Konsep anxiety juga dipandang oleh Bandura (1988) sebagai kurangnya keyakinan yang mempengaruhi suatu tindakan. Anxiety menandakan ketidaksiapan seseorang untuk menghadapi ancaman dari suatu tindakan (Bandura, 1988). Dari konsep tersebutlah kemudian computer anxiety dapat diketahui muncul dari rasa takut dan upaya antisipasi yang muncul pada diri seseorang (Harrison dan Rainer, 1992). Semakin tinggi rasa takut, maka kegelisahan yang dialami akan semakin tinggi pula, sedangkan apabila upaya antisipasi yang dilakukan semakin tinggi, rasa takutnya akan berkurang. Berkurangnya rasa takut akan meningkatkan keyakinan dan dapat meningkatkan minat. Hasil yang diperoleh pada studi ini mendukung penelitian terdahulu bahwa computer anxiety berpengaruh negatif terhadap persepsi minat menggunakan teknologi (Saade dan Kira, 2009; Hsiao et.al., 2010; Jahromi, et.al., 2016; Putra dan Nugroho, 2016). Hal tersebut dikarenakan terdapat kesamaan indikator pengujian sehingga hasil yang diukur menggambarkan keadaan yang serupa dimana rasa takut yang dimiliki pelaku UMKM lebih besar daripada rasa antisipasinya, sehingga ketika computer anxiety yang dimiliki tinggi, ketakutan juga akan tinggi, dan penggunaan IT akan menurun.

Hasil pengujian untuk hipotesis kedua pada Tabel 2 menunjukkan bahwa CSE berpengaruh positif terhadap minat untuk menerapkan teknologi informasi akuntansi. Artinya semakin tinggi efikasi diri dari pelaku UMKM terhadap penggunaan komputer, maka minat untuk menerapkan teknologi informasi akuntansi pada usahanya juga akan meningkat, dan sebaliknya pelaku UMKM dengan CSE rendah akan merasa kurang yakin atas kemampuannya sehingga menurunkan minatnya untuk menerapkan teknologi informasi akuntansi pada usahanya. Hasil ini membuktikan lagi bahwa di luar faktor yang terdapat dalam TAM yang dikembangkan oleh Davis (1986), masih terdapat faktor eksternal yang juga dapat mempengaruhi penerimaan teknologi yaitu CSE. Penggunaan CSE 
sebagai variabel eksternal sehingga mempengaruhi minat pada TAM juga sejalan dengan konsep self-efficacy dari Bandura (1986) yang menyatakan bahwa self-efficacy dapat mempengaruhi pilihan perilaku individu. Hal tersebut terjadi karena dengan adanya self-efficacy, seseorang akan berupaya untuk menghadapi rintangan sehingga mampu melewatinya, sehingga mereka akan lebih mudah menerima pekerjaan tersebut. Konsep semacam itulah yang kemudian juga diterapkan pada penerimaan penggunaan komputer oleh Compeau dan Higgins (1995) dalam CSE, dimana munculnya keyakinan akan membuat seseorang merasa mampu mengerjakan komputasi sendiri, mampu mengoperasikan berbagai perangkat yang ada pada komputer dan mampu menyelesaikan tugasnya dengan bantuan komputer. Seseorang yang memiliki CSE akan lebih mudah menerima penggunaan komputer dari pada mereka yang merasa tidak yakin. Hasil dari studi ini sesuai dengan penelitian terdahulu yang menyatakan bahwa CSE berpengaruh positif terhadapa penggunaan komputer (Putra \& Nugroho, 2016; Achim \& Kassim, 2015; Saade \& Kira, 2009; Hsiao et. al., 2010; Jahromi et. al., 2016;). Akibatnya, semakin tinggi CSE yang dimiliki pelaku UMKM, minat untuk menerapkan teknologi informasi akuntansi juga akan meningkat. Kesamaan tersebut dikarenakan baik definisi maupun instrumen pengukur CSE pada studi ini sama dengan studi terdahulu, sehingga hasil pengukurannya pun juga serupa.

Hasil analisis hipotesis ketiga pada Tabel 2 menunjukkan bahwa perceived usefulness berpengaruh positif terhadap minat untuk menerapkan teknologi informasi akuntansi. Artinya semakin para pelaku UMKM percaya bahwa penggunaan teknologi informasi akuntansi dapat memberikan manfaat kepada mereka, minat mereka terhadap penggunaan teknologi informasi akuntansi akan semakin meningkat. Hasil ini mendukung konstruk dari TAM yang dikembangkan oleh Davis (1986) dimana perceived usefulness digambarkam memiliki pengaruh langsung terhadap minat menggunakan teknologi. Perceived usefulness dianggap sebagai variabel utama yang dapat memotivasi individu untuk menerapkan. Bahkan, faktor perceived usefulness dianggap memiliki pengaruh yang signifikan terhadap penerimaan teknologi. Seperti yang dijelaskan oleh Venkatesh \& Davis (2000), seseorang yang menganggap bahwa penggunaan teknologi memberikan kegunaan, dapat meningatkan kinerjanya, meningkatkan produktivitasnya serta meningkatkan efektivitas kerjanya akan memiliki ketertarikan lebih untuk menggunakan teknologi tersebut daripada mereka yang tidak tahu manfaat tersebut. Hasil pada studi ini juga sesuai dengan berbagai studi terdahulu yang telah menyatakan bahwa perceived usefuness berpengaruh positif terhadap minat menerapkan teknologi (Hamid et. al., 2016; Elkaseh et. al., 2016; Renny et. al., 2013; Anggraeni, 2015). Hal ini menunjukkan bahwa sesuai dengan TAM, besarnya manfaat dari suatu teknologi yang disadari oleh para pengguna mendorong munculnya minat tersebut. Adanya kepercayaan bahwa dengan menggunakan teknologi tersebut akan membawa manfaat bagi usahnya, minat untuk menggunakannnya akan semakin meningkatkan, sedangkan apabila pelaku UMKM tidak mengetahui manfaat yang akan diperoleh mereka tidak akan berminat untuk menggunakannya.

\section{SIMPULAN}

Berdasarkan hasil studi yang dikaitkan dengan rumusan masalah, dapat disimpulkan bahwa computer anxiety memiliki pengaruh negatif terhadap minat pelaku UMKM untuk menerapkan teknologi informasi akuntansi, sedangkan computer self-efficacy (CSE) dan perceived usefulness justru berpengaruh positif terhadap minat pelaku UMKM untuk menerapkan teknologi informasi akuntansi. Hal tersebut membuktikan bahwa semakin tinggi kecemasan yang dialami oleh pelaku UMKM akan membuatnya semakin enggan untuk menggunakan komputer dalam kegiatan usahanya sehingga minat untuk menerapkan teknologi informasi akuntansi justru akan semakin berkurang. Sebaliknya, dengan semakin tinggi CSE yang menunjukkan bahwa semakin tinggi keyakinan diri yang dimiliki oleh para pelaku UMKM dalam menggunakan komputer, minat untuk menerapkan teknologi informasi akan meningkat. Sama halnya dengan CSE, semakin meningkatnya perceived usefulness atau persepsi pelaku UMKM atas kegunaan teknologi informasi akuntansi, minat untuk menggunakan teknologi tersebut akan semakin meningkat.

Dengan adanya hasil yang diperoleh tersebut, studi ini dapat berkontribusi secara teoritis pada TAM, terutama pada konstruk perceived usefulness terhadap minat, dimana dari hasil yang telah diperoleh dapat diketahui bahwa perceived usefulness telah terbukti dapat mempengaruhi minat 
secara positif. Selain itu, studi ini juga menambah kajian terkait variabel di luar konstruk utama TAM yang juga diketahui masih dapat berpengaruh terhadap minat, terlebih lagi yang berkaitan dengan unsur instrinsik, yaitu faktor yang berasal dari diri sendiri. Studi ini juga berkontribusi secara praktis kepada para pelaku UMKM sehingga mereka dapat mengetahui faktor yang meningkatkan maupun menurunkan minat mereka terhadap penggunaan teknologi informasi akuntansi, serta mempersiapkan diri mereka untuk menghadapi masuknya teknologi tersebut.

Proses studi ini tentu tidak luput dari berbagai keterbatasan. Pertama studi ini belum membagi UMKM berdasarkan tingkatan usaha mikro, kecil, dan menengah, sehingga dikhawatirkan hasil yang diperoleh hanya menggambarkan kondisi UMKM pada tingkat tertentu. Selanjutnya, pernyataan pada kuesioner jumlahnya sangat terbatas dikarenakan menyesuaikan karakteristik dan estimasi kesibukan dari pelaku UMKM yang dikhawatirkan enggan untuk menjawab terlalu banyak pertanyaan. Selain itu, pada variabel computer anxiety, computer self-efficacy dan perceived usefulness, peneliti mengadopsi pernyataan dari indikator berbahasa inggris, sehingga harus mengalihbahasakan sendiri. Jumlah responden dalam studi ini juga cukup sedikit jika dibandingkan dengan besarnya populasi yang ada. Meskipun data dapat digeneralisasikan, namun dengan lebih banyak sampel maka hasil yang diperoleh akan semakin mendekati kondisi yang sesungguhnya.

Untuk studi selanjutnya, penelitian yang berkaitan dengan penerapan teknologi informasi akuntansi dapat dilakukan memilah UMKM berdasarkan ukuran usahanya, sehingga hasil yang didapatkan benar-benar dapat digeneralisasikan ke semua jenis UMKM. Selain itu, studi selanjutnya juga dapat dilakukan pada kelompok masyarakat yang berbeda dan memiliki karakteristik unik, misalnya pada kelompok petani, pengelolaan pariwisata, kelompok aktivis masyarakat dan lainnya. Studi selanjutnya juga diharapkan untuk menambah jumlah pertanyaan yang ada pada kuesioner sehingga bisa memperoleh informasi lebih mendalam lagi. Dan lagi, studi selanjutnya diharapkan untuk menambah jumlah sampel yang akan diuji, sehingga dapat semakin mewakili populasi.

\section{DAFTAR RUJUKAN}

Achim, N., \& Kassim, A. A. 2015. Computer Usage: The Impact of Computer Anxiety and Computer Self-efficacy. Procedia - Social and Behavioral Sciences, 172, 701-708.

Andarsari, P. N., \& Dura, J. 2018. Implementasi Pencatatan Keuangan pada Usaha Kecil dan Menengah (Studi pada Sentra Industri Keripik Tempe Sanan di Kota Malang). Jurnal JIBEKA, 12(1), 59-64.

Anggraeni, R. 2015. Pengaruh Persepsi Kemudahan Penggunaan dan Persepsi Kegunaan Terhadap Niat Untuk Menggunakan dan Penggunaan Aktual Layanan Jejaring Sosial Berbasis Lokasi (Studi pada Mahasiswa Fakultas Ekonomi dan Bisnis Universitas Brawijaya Malang). Jurnal Ekonomi Bisnis, 20(1), 1-52.

Bandura, A. 1986. Social Foundation of thought and action. Englewood Clift, NJ: Prentice Hall.

Compeau, D. R., \& Higgins, C. A. 1995. Computer Self-Efficacy: Development of a Measure and Initial Test. MIS Quarterly, 19(2), 189-211.

Davis, F. D. 1986. A technology acceptance model for empirically testing new end-user information systems: theory and results. PhD Dissertation. Massachusetts Institute of Technology, Cambridge.

Davis, F. D., Bagozzi, R. P., \& Warshaw, R. P. 1989. User Acceptance of Computer Technology: A Comparison of Two Theoretical Models. Management Science, 35(8), 982-1003.

Dawuda, A., \& Azeko, I. 2015. An Assessment of Financial Records Keeping Behavior of Small Scale Businesses in Ghana: A Case Study of Bolgatanga Municipality. International Journal of Finance and Accounting, 4(3), 187-194.

Elkaseh, A. M., Wong, K. W., \& Fung, C. C. 2016. Perceived Ease of Use and Perceived Usefulness of Social Media for e-Learning in Libyan Higher Education: A Structural Equation Modeling Analysis. International Journal of Information and Education Technology, 6(3), 192-199.

Ezeagba, C. 2017. Financial Reporting in Small and Medium Enterprises (SMEs) in Nigeria. Challenges and Options. International Journal of Academic Research in Accounting, Finance and Management Sciences, 7(1), 1-10.

Ghozali, I. 2009. Aplikasi Analisis Multivariate Dengan Program IBM SPSS (Edisi 5). Semarang: 
Badan Penerbit UNDIP.

Hamid, A. A., Razak, F. Z. A., Bakar, A. A., \& Abdullah, W. S. 2016. The Effects Of Perceived Usefulness And Perceived Ease Of Use On Continuance Intention To Use E-Government. Procedia Economics and Finance, 35(2016), 644-649.

Hanggono, A. A., Handayani, S. R., \& Susilo, H. 2015. Analisis Atas Praktek TAM (Technology Acceptance Model) Dalam Mendukung Bisnis Online Dengan Memanfaatkan Jejaring Sosial Instagram. Jurnal Administrasi Bisnis, 26(1), 1-9.

Harrison, A. W., \& Rainer, R. K. 1992. The influence of individual differences on skill in end-user computing. Journal of Management Information Systems, 9(1), 93-111.

Hesam, D. 2017. Impact of Information Technology in Evolution of Traditional Accounting To Modern Accounting. International Journal of Management and Applied Science, 3(5), 11-14.

Hsiao, H. C., Tu, Y. L., \& Lin, Y. R. 2010. Computer Self-efficacy, Computer Anxiety, and Attitudes Toward Computers:A Study of Vocational High School Teachers in Taiwan. Procedia-Social and Behavioral Sciences, 172(2015), 701-708.

Igbaria, M., Schiffman, S. J., \& Wieckowski, T. J. 1994. The respective roles of perceived usefulness and perceived fun in the acceptance of microcomputer technology. Behaviour \& Information Technology, 13(6), 349-361.

Irmadhani, \& Mahendra, A. N. 2012. Pengaruh Persepsi Kebermanfaatan,Persepsi Kemudahan Penggunaan dan Computer Self-Efficacy, Terhadap Penggunaan Online Banking. Kajian Pendidikan \& Akuntansi Indonesia, 1-20.

Jahromi, S. A. F., Forouzan, A., \& Gholaminejad, R. 2016. Computer Anxiety and Computer SelfEfficacy as Predictors of Iranian EFL Learners' Performance on the Reading Section of the TOEFL iBT. Higher Education of Social Science, 11(6), 55-65.

Kanchanatanee, K., Suwanno, N., \& Jarernvongrayab, A. 2014. Effects of Attitude toward Using, Perceived Usefulness, Perceived Ease of Use and Perceived Compatibility on Intention to Use E-Marketing. Journal of Management Research, 6(3), 1.

Kemkominfo. 2017. Kemkominfo Ajak UMKM di Kota Malang Go Online. Pemerintah Kota Malang 2. Retrieved from https://malangkota.go.id

Kurniawan, R., \& Diptyana, P. 2011. Telaah Pemanfaatan Software Akuntansi. The Indonesian Accounting Reviewer, 1(2), 107-116.

Kurniawati, E. P., Nugroho, P. I., \& Arifin, C. 2012. Penerapan Akuntansi pada Usaha Mikro Kecil dan Menengah (UMKM). Informatics and Business Institute Darmajaya, 10(2).

Lee, D., Park, J., \& Ahn, J. 2000. On The Explanation of Factors Affecting E-Commerce Adoption. In Proceedings ICIS 2001 (pp. 1-21).

Lestiawan, H., \& Mahmud. 2014. Purwarupa Pembelajaran Mandiri Sistem Aplikasi Akuntansi Umkm Berbasis Web Dalam Pemberdayaan Usaha Masyarakat Jawa Tengah. In Prosiding SNATIF (pp. 445-452).

Lindblom, K., Gregory, T., Wilson, C., Flight, I. H. K., \& Zajac, I. 2012. The impact of computer self-efficacy, computer anxiety, and perceived usability and acceptability on the efficacy of a decision support tool for colorectal cancer screening. Journal of the American Medical Informatics Association, 19(3), 407-412.

Nunnally, J. (1967). Psychometric Methods. New York: McGraw-Hill.

Putra, A. K., \& Nugroho, M. A. 2016. Pengaruh Computer Anxiety Computer Attitude Dan Computer Self Efficacy Terhadap Minat Menggunakan Software Akuntansi the Impacts of Computer Anxiety, Computer Attitude and Computer Self. Jurnal Profita Universitas Negeri Yogyakarta, (3), 1-19.

Rakhmawati, S., \& Isharijadi, I. 2013. Pengaruh kepercayaan, persepsi kegunaan, persepsi kemudahan, dan persepsi kenyamanan terhadap minat penggunaan sistem internet banking pada nasabah bank muamalat cabang pembantu madiun. Jurnal Akuntansi Dan Pendidikan, 2(2), 71-78.

Renny, Guritno, S., \& Siringoringo, H. 2013. Perceived Usefulness, Ease of use, and Attitude Towards Online Shopping Usefulness Towards Online Airlines Ticket Purchase. ProcediaSocialand Behavioral Sciences, 81(2013), 212-216. 
Rosianti, N. C., \& Mahendrawati, E. R. 2017. Analisis Tingkat Kematangan Proses Bisnis Dan Kesiapan Teknologi Informasi Studi Kasus Usaha Garmen Mikro, Kecil, Dan Menengah Di Jawa Timur. Jurnal Teknik ITS, 6(2), 264-269.

Rumetna, S., \& Sembiring, I. 2017. Pemanfaatan Cloud Computing Bagi Usaha Kecil Menengah (UKM). In Prosiding Seminar Nasional Geotik 2017 (pp. 1-9).

Saade, R. ., \& Kira, D. 2009. Computer Anxiety in E-Learning: The Effect of Computer Efficacy. Journal of Information Technology Education, 8(1), 1-16.

Saban, M., \& Efeoglu, Z. (2012). An Examination of the Effects of Information Technology on Managerial Accounting in the Turkish Iron and Steel Industry. International Journal of Business and Social Science, 3(12), 105-117.

Siregar, S. 2013. Metode Studi Kuantitatif. Jakarta: PT Fajar Interpratama Mandiri.

Sugiyono. 2014. Metode Studi Pendidikan Pendekatan Kuantitatif, Kualitatif Dan R\&D. Bandung: Alfabeta.

Thompson, R. L., Haggings, C. A., \& Howell, J. 1991. Personal Computing: Toward a Conceptual Model of Utilization. MIS Quarterly, 125-143.

Venkatesh, V., \& Davis, F. D. 2000. A Theoretical Extension of The Technology Acceptance Model: Four longitudinal field studies. Management Science, 46(2), 186-204.

Venkatesh, V., Speier, C., \& Morris, M. G. 2002. User Acceptance Enablers in Individual Decision Making About Technology: Towards an Integrated Model. Decision Sciences, 33(2), 297-316.

Welliam, T. 2012. Pengaruh persepsi kegunaan, e-service quality, dan e-loyalty program terhadap minat menggunakan ulang website Gramedia online. Jurnal Wima, (2012), 1-7. 